Article

\title{
Unraveling the Relationship between Collective Action and Social Learning: Evidence from Community Forest Management in Canada
}

\author{
Anderson Assuah * and A. John Sinclair \\ Natural Resources Institute, University of Manitoba, Winnipeg, MB R3T 2N2, Canada; \\ john.sinclair@umanitoba.ca \\ * Correspondence: assuaha@myumanitoba.ca; Tel.: +12-048-876-163
}

Received: 30 March 2019; Accepted: 4 June 2019; Published: 9 June 2019

check for updates

\begin{abstract}
An important outcome of social learning in the context of natural resource management is the potential for collective action-actions taken by a group of people that are the result of finding shared or common interest. Evidence of the relationship between collective action and social learning is beginning to emerge in the natural resource management literature in areas such as community forestry and participatory irrigation, but empirical evidence is sparse. Using a qualitative inquiry and research design involving a case study of the Wet'zinkw'a Community Forest Corporation, this paper presents research that examined the relationships between collective action and social learning through community forest management. Our findings show strong evidence of collective action outcomes on the part of board members responsible for the community forest, such as establishing a legacy fund, adding value to logs, protecting First Nations cultural values, and hiring locally. Our data also reveal that the actions taken by board members were encouraged through social learning that was related to acquiring (new) knowledge, developing an improved/deeper understanding, and building relationships. However, we found limited opportunities for community forest partners and the general public to learn and contribute to collective action outcomes since the actions taken and associated learning occurred mainly among board members.
\end{abstract}

Keywords: collective action; social learning; community forest management; Canada

\section{Introduction}

Evidence clearly suggests that social learning is important to creating a path forward in relation to complex natural resources management decisions [1,2]. As established by Woodhill and Röling, such learning can "help improve the quality and wisdom of the decisions we take when faced with complexity, uncertainty, conflict and paradox" [3] (p. 54). Social learning typically involves participants sharing their opinions, ideas, and knowledge, as influenced by their backgrounds, interests, experiences and/or beliefs about how resources should be managed. This opportunity to share diverse perspectives and views allows for deliberations that can facilitate joint problem solving and empower participants to alter their thinking and previously held knowledge to identify new directions [4,5]. For instance, social learning can result in participants improving their understanding of the resource being managed and the management processes, and acquiring new skills [6,7]. Decision-making and management that includes learning opportunities also helps build trust and relationships among participants, while changing decision-making practices and improving approaches to managing resources [8-10].

Natural resource management/governance approaches that are collaborative and deliberative in orientation are recognized as encouraging social learning [11-13]. Research shows that community forestry, which devolves forest management responsibilities to communities, is an example of a 
governance approach that can combine collaboration, deliberation, and learning effectively at a regional scale $[4,14]$. In Canada, the community forestry model offers local citizens and forest stakeholders, who hold a broad array of knowledge, expertise, and experience, the opportunity to collaborate around the management of local forests and make management decisions for the benefit of the community at large. In doing so, opportunities exist for participants to learn together while trying to manage their forest as sustainably as possible [15].

The literature establishes that a possible outcome of social learning is the potential for collective action among participants or collaborators. In fact, social learning is viewed as the "... basis for joint action" [11] (p. 311). Keen and associates agree with this and go on to define social learning as "the collective action and reflection that occurs among different individuals and groups, as they work to improve the management of human and environmental interrelations" [16] (p. 4). Similarly, Ducrot views social learning as "learning processes among a group of people who seek to improve a common situation and take collective action" [17]. Notwithstanding these claims, some authors support scrutiny into the assertion that collective action is an outcome of social learning, given the limited empirical evidence available [18].

Evidence of collective action outcomes resulting from social learning is beginning to emerge in many sectors, including community forestry. For example, in analyzing two Bolivian communities in which social learning projects were implemented, Biedenweg and Monroe found that participants, among other things, were involved in "timber monitoring and contract negotiations, and were more likely to discuss collective sales of Brazil nuts ... " [19] (p. 251). Egunyu and Reed also found collective action in the form of a forest patrol implemented by the Kapeeka Integrated Conservation Development Agency in Uganda [7]. While these studies identify collective action initiatives, the evidence of such outcomes as a result of social learning is sparse and the learning processes that engender such collective action also need investigation. Given this, the aim of our study was to examine the collective action that resulted from a community forest (CF) governance approach, and the relationships between the action and social learning outcomes. As such, we aimed to identify collective action outcomes as defined in the literature and to explore whether any such outcomes were the direct result of social learning. To ground this analysis, we adopted the definition of social learning by Schusler and associates, which is "learning that occurs when people engage one another, sharing diverse perspectives and experiences to develop a common framework of understanding and basis for joint action" [11] since it recognizes both learning and action as being at the core of social learning.

\subsection{Collective Action}

Collective action has engendered several definitions and conceptualizations in natural resources and environmental management. For instance, it is defined as occurring "when more than one individual is required to contribute to an effort in order to achieve an outcome" [20]. This definition establishes that collective action requires the meeting of individuals involved in managing resources to discuss rules and how to go about achieving an outcome. According to Collective Action and Property Rights "Collective action can be understood as an action or series of actions taken by a group of individuals to achieve common interests" [21]. This action can be voluntary or an obligation for those involved; however, the actions of paid, hired, or forced labour are not considered collective action $[21,22]$.

Meinzen-Dick and associates provide a cogent synthesis of the key components of collective action, stating that the concept "requires involvement of a group of people, it requires a shared interest within the group, and it involves some kind of common action that works in pursuit of that shared interest" [22] (p. 200). The authors also emphasize that the action should be voluntary and include actions such as "collective decision-making, setting rules of conduct of a group and designing management rules, implementing decisions, and monitoring adherence to rules" [22] (p. 200). Similarly, Keen and associates suggest that in a social learning context, participants can contribute to decision-making and actions to improve management of natural resources or the environment through 
sharing their perspectives, deliberating about those together and taking action to modify decision processes as necessary [16].

In this paper, we adopted the conceptualization of collective action by Meinzen-Dick and associates for the following reasons. First, we focused our work on the board of a CF-a group of voluntary community members-as the locus of learning and action. Second, members of the board have a common or shared interest in forestry issues as evidenced by their involvement with the CF. Third, the board is responsible for making collective decisions regarding how the CF should operate and be managed. Finally, the board offers direction for the $\mathrm{CF}$, as well as establishing the rules of engagement and management on behalf of the $\mathrm{CF}$ and the community. Thus, we considered collective action in the context of CF board members working together (and with forest user groups and a First Nation) and contributing to collective decisions to manage the forest in ways that met the shared interests of the board and community.

\subsection{Context and Associated Case Focus}

The Province of British Columbia has the longest history with community forestry in Canada, with the first CF dating back to 1958 [23]. In 1998, the British Columbia government passed the Forest Statuses Amendment Act to pilot a new form of forest tenure-Community Forest Agreements-in the Province [24]. Ten CFs were piloted. In 2004, the government introduced a five-year probationary license to communities that applied for a CF license [24].

This probationary license was finally replaced in 2009 with 25-year renewable CF agreement licenses to allow for long-term forest management planning, as well as enabling the creation of ongoing business relationships [24]. The British Columbia (BC) Community Forest Association estimates that as of May 2018, there were about 63 CFs at several stages of operation and or planning in the Province [25]. The Community Forest Program in BC therefore provided one of the most robust opportunities in Canada for the study of community forestry.

Our study focused on the Wet'suwet'en Community Forest Corporation (WCFC), which was awarded a 25-year renewable CF in 2010 to manage a 32,000-hectare forest. WCFC's license is jointly held by the Town of Smithers and the Village of Telkwa-equal shareholders-who manage the forest together with the Wet'suwet'en First Nation and forest users (e.g., skiers, backpackers). The WCFC is governed by a board of seven volunteers that oversees the strategic management of the corporation. A local forest company, Silvicon Services Inc., is contracted to run forestry operations. The board makes decisions on the CF with input from interested stakeholders such as forest users, while Silvicon Services Inc. applies this guidance in harvesting the forest.

In choosing the WCFC, we selected the most active CFs in BC and applied the following five criteria based on evidence collected through web sites and the literature: evidence of an on-going process of multi-stakeholder collaboration in forest management; a decision structure that allows for representation of the larger community on a board, committees, and sub-committees; opportunities for face-to-face deliberation between members of the board/committees and the larger community; regular meetings of the board/committees and between the board and the larger community; and, some evidence of learning through innovative governance or forest management or evidence of alternative forest resource management other than timber. From this analysis seven $\mathrm{CFs}$ were selected for further consideration, and the lead author phoned and talked to those in charge of managing these CFs to help make an informed decision about the choice of a CF. The communication focused on how the above criteria actually play out on the ground.

From these seven CFs, WCFC was chosen to be our focus. The information gathered on WCFC revealed that their governance structure was likely collaborative and that there were opportunities for deliberative learning among forest user groups and interested community members. For example, their structure allows a new director-at-large to join the board each year to bring new ideas to discussions and decisions. Furthermore, we found that board members share ideas, discuss, and deliberate on issues through a range of activities such as monthly board meetings, annual general meetings, forest 
visits, and informal discussions among themselves. There was also documentation of forest user group meetings and informal discussions among community members and the board that was shared with us by WCFC's general manager. Finally, we found that WCFC had upcoming activities, which would allow opportunities to observe first hand their deliberation and any resultant learning. These activities included road construction for harvesting, silviculture prescriptions, site plan formulation, and an annual general meeting.

\section{Materials and Methods}

Given that we wanted to find out about both social learning and collective action outcomes from the people involved in the CF, we approached the research using a qualitative case study [26]. Four data collection methods were used: semi-structured interviews, participant observation, guided forest visits and document review. In terms of sequence, documents available on line such as annual reports and WCFC board meeting minutes were reviewed prior to the field activities and this work continued during the field research as new documents came to light. In the field, the work started with semi-structured interviews, with forest field visits, and observations incorporated as the interviews unfolded. Each of these is described below.

A number of documents related to WCFC activities were reviewed, including board and WCFC policies, forest stewardship and management plans, financial statements, and memoranda of understanding between WCFC and forest user groups. Data from documents helped to refine interview questions and provided the basic record of management practices. Semi-structured interviews were conducted by the lead author with 30 participants (face-to-face) that were involved in some way with the activities of the WCFC such as current and former board members, forest user groups, property owners, a contractor and a municipal Councilor. Interviews explored learning outcomes for participants, how they learned about forest issues, and collective actions taken while managing the forest. Further, the interviews explored participants' contributions to the WCFC, and ways they are learning to manage their CF sustainably.

In addition, the lead author attended an annual general meeting organized by the WCFC, participated in the meeting to observe deliberations among participants, and took notes regarding the discussions and decisions made as they related to the objectives of the research. The lead author also went on three guided forest walks, each five hours long. The first walk helped to familiarize the lead author with the WCFC forest area. Subsequent walks provided opportunities to observe the forest management practices and operations of the WCFC and to see in practice some of the forest management activities noted in interviews. During forest visits, photos and field notes were taken. Data for the research were gathered from September 2013 to December 2013.

The interviews, field observation notes and data from WCFC documents were transcribed and organized into themes with the aid of NVivo ${ }^{\mathrm{TM}}$ (QSR 2010) software. The key themes related to social learning were drawn from the literature, including relationship building, increased/better understanding of forestry issues, new knowledge, among others (see Table 1). As well, themes related to collective action were grounded in the data gathered (see Table 1). Predetermined themes for establishing the relationship between action and learning do not exist in the literature, so our findings in this regard are also grounded and come from the data and our analysis. In some cases, board members directly established the relationship between a collective action outcome and the social learning outcomes they noted. We were also able to determine these relationships, as well as verify them, by reviewing documents such as board minutes and reports and through on-site forest visits, where we could see some of the outcomes. By utilizing all of the methods above, the data revealed a number of specific learning outcomes and we were able to relate three of these outcome themes (New Knowledge, Increased/Deeper understanding, and Building Relationships) to the 14 collective action results we were able to document. Unless otherwise stated, we present the data using participant quotes. The quotes selected best represent the views of the majority of participants, unless we state otherwise. Individual participants are referred to by number to maintain confidentiality. 
We acknowledge that this is a single case study and a single data point gathered over a short period of time. As a result, the paper's findings are limited in their general applicability to other cases, but as noted above, most CFs have active multi-party governance systems, so there will be similarities to other CFs. It is also worth noting that other authors have identified social learning outcomes from community forestry [7,19].

All participants gave their informed consent before participating in this study. The study was conducted in accordance with the Declaration of Helsinki, and the protocol was approved by the Joint Faculty Research Ethics Board at the University of Manitoba (Protocol \#J2013:134).

Table 1. Social learning outcomes and associated collection action outcomes.

\begin{tabular}{cc}
\hline Social Learning Outcomes & Collective Action by the Wet'zinkw'a Community Forest Corporation \\
\hline (New) Knowledge & $\begin{array}{c}\text { Supported community initiatives } \\
\text { Provided monetary donations } \\
\text { Hired locally }\end{array}$ \\
\hline Forest governance & $\begin{array}{c}\text { Clear-cut trees affected by mountain pine beetle } \\
\text { Sustainable forest management and climate change }\end{array}$ \\
\hline Operating a forestry business & Developed an integrated resource management initiative \\
\hline Building relationships & $\begin{array}{c}\text { Experimented to add value addition to logs } \\
\text { Invested in a legacy fund } \\
\text { Invested in a silvicultural fund }\end{array}$ \\
\hline With forest users & $\begin{array}{c}\text { Signed MOUs with forest user groups } \\
\text { Supported forest user groups financially }\end{array}$ \\
\hline With First Nations & $\begin{array}{c}\text { Protected First Nation interests and cultural values } \\
\text { Experimented with propagating huckleberries and blueberries } \\
\text { Collaborated with First Nation to design informational posters }\end{array}$ \\
\hline
\end{tabular}

\section{Results}

Our results are organized around the three social learning themes and sub-themes revealed in the data (e.g., New Knowledge) and the associated collective action outcomes identified through our analysis (e.g., supported community initiatives) as established in Table 1. We consider each of these collective action outcomes in turn below and discuss their relation to the social learning outcomes in Section 3.7.

\subsection{Sharing Benefits}

An important component of community forestry is management for the benefit of local communities as opposed to industrial corporations $[27,28]$. This component was underscored to those proposing the WCFC during consultations with stakeholders, who felt this must be a central factor of any CF. Community members were told that the WCFC would generate profits that would be used to support local initiatives and provide direct monetary benefits, among other results. The board, therefore, acted to fulfill these promises by establishing an annual grants program. The grants supported community projects and initiatives such as the Wet'suwet'en Language and Culture Camp by the Office of the Wet'suwet'en and the Telkwa Elevator Project by Telkwa Christian Reformed Church. Information on community projects and initiatives that have been supported by WCFC can be accessed at http://wetzinkwa.ca/grant-program/.

In addition, monetary donations were given to community organizations such as the Mountain Bikers Association, Smithers Community Forest Corporation, and the Bulkley Valley Cross Country Ski Club. For instance, we found that monetary donations were instrumental in helping the Ski Club build its Hudson Bay Mountain Road Underpass. Furthermore, the WCFC developed a 100\% local hiring policy, providing employment to local loggers, tree planters, etc. For example, First Nation 
contractors within the Bulkley Valley were hired to do beetle probing and burning activities in the 2008/2009 logging season.

\subsection{Governance}

We also found collective action was needed to develop a governance response to the issues of beetle-infested wood. In the face of challenges posed by mountain pine beetle infestation, which threatened the sustainability of the landbase, there was need for the board's direction. Consequently, the board decided to clear-cut trees impacted by the beetle infestation after comparing management practices from other $\mathrm{CF}$ s and consulting with forest users and other interested stakeholders. It was explained that "[The board] had some of the results from Burns Lake and Prince George regarding how they had tried to deal with the pine beetle. So, we had results on what worked and what did not work ... there was no need doing these little wee patches, because you go and log that wee patch and did not get all the beetles around it" (Participant 5). Once the board was convinced that clearcutting was best for the CF, they sought permission from the province to increase WCFC's annual allowable cut, which was granted, but this action did not occur without resulting local concerns.

\subsection{Sustainable Forest Management and Climate Change}

The board also took action to initiate an ambitious integrated resource management initiative aimed at ensuring forest health and resiliency on the landbase in its efforts to deal with climate change and ensure sustainability. The initiative involved recovery of whitebark pine (Pinus albicaulis Engelmann); planting western larch (Larix occidentalis Nuttall) and Douglas fir (Pseudotsuga menziesii (Mirbel) Franco) in anticipation of climate change; and funding grant proposals. For example, the WCFC supported a local researcher with $\$ 4000$ to assist with the recovery of whitebark pine that "is an endangered tree [species] and is red-listed across Canada" (Participant 10). As well, sites on the CF tenure were provided for planting whitebark pine.

Likewise, the board responded to the need of the College of New Caledonia researchers for study sites. The board provided land for the College to install equipment necessary for site preparation for planting western larch and Douglas fir. It is worth noting that Western larch and Douglas fir are two species that are not approved by the Province for the Bulkley Valley. Their experiment on the landbase, however, showed some innovation, as they sought to maximize the $10 \%$ allowance to experiment with non-approved species in their forest stewardship plan. It was also explained that "We [WCFC] are not aware of how western larch and Douglas fir are going to do on the land. They might not grow well in the short term, so how we make sure that they survive in the long-term is the question" (Participant 1).

\subsection{Running a Forestry Business}

Board members revealed that they had to work carefully and creatively together to profitably manage the $\mathrm{CF}$ in order to ensure its long-term existence. This required the board to learn about the actions necessary to run WCFC as a business. In doing so, the board looked for ways to add value to logs as a business opportunity (Table 1). In one of these trials, Northern Engineered Wood Products, a local company that manufactures particleboard, was involved to process slash piles of wood into fibre. The company bought the machine needed to process the slash piles for the company's use and also supply a local pulp mill in Kitimat that used fibre as a raw material. Participant 3 indicated that "We [WCFC] were the first to try that in the bush. We gave the fibre to them; they did it, so we can see if there was a business, or if they could just take away the fibre from us." However, the business could not proceed because the "pulp mill closed down, and there was no need for that fibre ... there was a lot of fibre on the market, and the company felt there wasn't any need to operate this machinery" (Participant 3). The WCFC alone could not operate the machine nor transport fibre to other mills because of the high operating costs involved.

The board additionally experimented with making fence poles out of the slash piles and selling the poles to a local business in the Bulkley Valley. In this trial, tree tops were processed into particular 
dimensions specified by the company. The fence pole business looked promising at the start, but "for a variety of reasons, it was not economically viable, so we could not continue" (Participant 3). Moreover, the board engaged the services of a not-for-profit forest research institute to assess the prospect of transforming slash piles into bio-energy. It was concluded that it was not favourable for WCFC to proceed with the initiative in the short term, because the economics of doing such work was not favourable [29].

Realizing that WCFC was making a lot of profit from the increase in its annual allowable cut, the board started to explore investment options for the establishment of a legacy fund (Table 1). The goal of this fund is to put money in the bank from which income will be drawn. The board "is creating a legacy fund to contribute to innovative initiatives and stewardship in the community ... This will prevent us from depending on logging, because there are years we wouldn't be able to harvest much" (Participant 2). The target for the legacy fund, which we cannot disclose because of confidentiality concerns, was achieved after the 2013 and 2014 harvesting season.

The board also made the decision to invest in a silviculture fund as part of running the CF as a business. With this fund, $\$ 4.50$ per cubic metre of wood harvested is set aside. "Every time we harvest, we have money to re-forest in the next 15 years plus more. We are a little conservative as a board, putting down more money than we require," said a board member.

\subsection{Building Relationships with Forest Users}

As Table 1 indicates, the board took action on three key initiatives related to building relationships with forest users. These initiatives were the board's way of ensuring that forest management would work in harmony with forest users-e.g., bikers and skiers. To help achieve this, the board signed a memorandum of understanding (MOU) with the groups in regard to respecting their activities and working to incorporate their views into management plans (Table 1). Furthermore, the WCFC financially "supports these recreation groups to develop and maintain their infrastructure on the landbase," (Participant 2). Moreover, the WCFC maintains roads on the landbase to enhance trail management by recreational groups. Commenting on this latter action by the WCFC, a member of the Bulkley Valley Cross Country Ski Club recounted:

"For us, this is huge because if the roads weren't there, our trails wouldn't be there ... I look at the engagement between the Ski Club and the CF, and I see their close relationship in there. I look at how they have managed their harvest very well and also done a bunch of hazard tree removal to the advantage of the Ski Club. This shows that there is a good collaboration going on there" (Participant 20).

Additionally, board members mentioned that "... in the past, we created interpretive trails for hikers and demonstrating interpretive signs. We have been working with the mountain bikers to ensure that we are not impacting their trails on the landbase" (Participant 2). Participants indicated that WCFC collaborated with the ski club in one of its logging operations to the satisfaction of the latter and shared profits with them.

The board has also taken action to incorporate the views of forest user groups into management plans and this has become a very important action in regard to relationship building. The WCFC organizes a resource user group meeting at least once a year to discuss management of the forest tenure, and also garner input from forest user groups regarding management plans. Besides these meetings, representatives of forest user groups revealed that they were able to approach board members anytime to discuss their concerns. "We showed a map of where we wanted to develop [trails] and how that is going to affect harvesting and listened to any concerns WCFC had ... We provided them with data, which they incorporated into their plans, so they left a buffer [around the trails] ... It made an impact just talking to them," said a member of the Smithers Mountain Bike Association. 


\subsection{Working with First Nations}

The board has worked together on initiatives related to building relationships with the Wet'suwet'en First Nation. One such action included protecting Wet'suwet'en interests and cultural values on the landbase (Table 1) based on data and information provided by the Wet'suwet'en. A Wet'suwet'en participant explained that "the board and general manager, without any challenges, have dropped some of the cutting permits in significant areas for the Wet'suwet'en ... We had one of the cutting permits withdrawn completely from the plans; there were also some valuable timber stands that the general manager dropped because of the Wet'suwet'en values." Another Wet'suwet'en participant revealed that "the general manager develops the cutting permits and ... we [Wet'suwet'en] have a referral coordinator that gets to see the operational plans before they are formalised, and gets to make changes ... The referral coordinator, through the Office of the Wet'suwet'en, provides a letter of support to the plans once everything is okay." Also, "there are culturally modified trees that we [Wet'suwet'en] take time to GPS, so they are protected on the landbase after forest activities," said Participant 2.

Furthermore, the board supported the Wet'suwet'en with financial resources to help experiment and propagate blueberries and huckleberries on the landbase. The berry trial was done in a greenhouse and it was hoped that a successful outcome would allow the Wet'suwet'en to plant the berries on the landbase. This project did not materialize fully because of poor results from the trials. Finally, the board and Wet'suwet'en hereditary chiefs have collaboratively designed interpretive posters (Table 1) that are displayed at a gathering shelter built by the WCFC. The posters are geared towards engaging the public and helping them to learn about the activities of the CF and the Wet'suwet'en. The gathering shelter was constructed along one of the Wet'suwet'en traditional gathering places, which is the hub of a number of trails. The shelter is open to the public to host picnics or any other gathering.

\subsection{Examining the Collective Action-learning Relationship}

Three of the outcomes of social learning were central to enabling the collective action outcomes (data) presented above: (new) knowledge, improved or better understanding, and relationship building $[14,18,19]$. Table 1 shows the social learning outcomes that drove the collective actions found in the data. We discuss each of these below and explore the learning attributes that helped enable collective action outcomes. It is important to note that we found evidence of a number of other social learning outcomes, such as trust building and the acquisition of social skills, but we did not find evidence that they resulted in collective action by participants.

\subsection{1. (New) Knowledge}

Board members underscored the importance of what they learned from other CFs in terms of their discussions and decisions about the distribution of profits to their communities. Through deliberations and discussions among themselves, they took what they learned from other CFs and modified it to establish an approach that best fit the WCFC. Learning the best ways to distribute profits was particularly important in the face of high expectation for benefit sharing with the community. A board member noted:

\footnotetext{
"One of the things that WCFC has done in terms of being successful is looking at other CF structures and some of the positives and challenges that those CFs faced ... There have been examples of other CFs in BC that were building empires and owning certain corporations and trying to get community benefits from that ... We wanted to keep things simple by encouraging economic and social growth ... that was how we wanted to share profits with the community" (Participant 2).
}

In addition to learning from other community forests, board members learned from their colleagues that had prior experience with distributing funds in the community. Participant 2 noted that: "... One of our previous directors was involved with the Mountain Equipment Co-op Grant Program, so we 
utilised a lot of those ideas and the format for our community grants evaluation from the previous work that had been done by the director. And that has enhanced the ability of the CF to do due diligence and share some benefits to the communities." The culmination of the learning among the board resulted in the action taken in fund distribution such as through supporting community initiatives, providing monetary donations, and hiring locally, as indicated in Table 1.

In regard to learning how to govern/manage WCFC, we were told that managing a CF required learning about the various structures and setups needed for a successful forestry operation. Data revealed that learning on the board in this regard spanned across administration, forestry regulations, planning, and other areas. Particularly at the outset of the $\mathrm{CF}$, board members had to learn from other CFs regarding their set-up and the sort of things they needed to do to effectively manage the forest. "I remember at a point, [name withheld] was tasked to find out from other CFs how they had set up. So, we were trying to learn from other models as to how things were working" (Participant 11). More specifically, the board has "learned about administration and how the job [forest operations] is done. I did four field trips personally when I was on the board, where we went to look at cut blocks, how they were logged, who we were dealing with, and the various agreements [with forest user groups]" (Participant 13). As a result, board members indicated they have " ... broader awareness of the whole [forest governance/management] process: from planning to layout, legislation, stumpage rate, the numbers, and what it takes to stay profitable" (Participant 4). It was through such learning that the board decided to clear-cut beetle-infested trees having gained insight into successful and unsuccessful approaches utilized by other CFs. The lead author, through forest visits, observed beetle-infested areas which were clear-cut. These areas were also designated in logging plans.

\subsubsection{Increased/Deeper Understanding of Forestry Issues}

Board members indicated that they had deepened their understanding of issues related to climate change and sustainable forest management by learning from colleague board members with forestry backgrounds and experience, through presentations made to the board by the company contracted to oversee daily operations on the landbase, as well as through researchers working on the landbase. According to Participant 7, “[A board member's] knowledge of whitebark pine ... taught me about a strategy that aims to increase the resilience of the forest in the face of climate change by diversifying the species composition." A second participant recounted, "Another thing I learned was with climate change ... to get different species to keep the normal process but faster. To get different species in different areas, Douglas fir and larch will be planted to give a diversity of species on the land." Participants indicated that the board's deeper understanding of climate change and sustainable forest management issues helped shape the content of the integrated resource management initiative, which was first proposed by a board member who felt the board could do something ecologically different on the landbase. For example, they planted non-traditional tree species to improve forest health. In the end, a plan was developed and it was extensively discussed and deliberated on at the board's strategic meetings to give it the needed structure [29]. Consequently, the board started a recovery strategy for whitebark pine, and planted western larch and Douglas fir to deal with climate change, as called for in its integrated resource management initiative.

On running a forestry business, board members felt they needed to deepen their understanding of the business aspects of managing the forest, particularly because of their varied backgrounds. Participant 7, for instance, explained that the board "learned more about the business side of forestry. This was something I had not been exposed to before in such an operational way. This gave me a deeper understanding and appreciation for the context of community forestry and the trade-offs that communities have to make when attempting to manage the forest for a wide range of values, while running a viable enterprise ... "Another board member explained that "I didn't have a lot of knowledge in stratifying the value of the logs ... So, learning about the things you need to consider before marketing the fibre to get a lot of return is something I didn't really have a lot of knowledge about before." Specifically, on establishing the legacy fund, the board explored investment options 
among themselves and also hired the services of " ... a financial advisor with the Royal Bank of Canada to advise us on a portfolio for the reserve funds with the intent that we are going to roll the money we have been making into operations, because for two or three years now, WCFC has been making a lot of money because we have been harvesting beetle wood" (Participant 7). Learning together through experience and with the help of others to run a business resulted in actions to establish a legacy fund, a silvicultural fund, and ways to add value to harvested logs (Table 1).

\subsubsection{Building Relationships}

The data show that the board has learned that building relationships with other forest users, and finding effective ways to do that, is central to managing the CF. Understanding how to build relationships with these groups was noted as important since "recreational use is contentious in the Bulkley Valley ... every group wants the other's activities excluded" (Participant 14). According to board members, they learned to work with forest user groups based on interactions with forest users and their experiences living in the community. Explaining the motivation to continually build relationships with forest groups, a board member explained that "... Though it is our right to harvest and manage all these areas [landbase], we recognise the value of the visual impact [of our operations] to their recreation."

Moreover, the board is continually trying to learn ways to build stronger relationships with the Wet'suwet'en First Nation on whose land the WCFC tenure is located. This relationship started at the outset of the WCFC. Participant 23 indicated that the relationship is a result of "openness and understanding [between WCFC and the Wet'suwet'en]". A Wet'suwet'en participant explained that " ... the municipalities wanted to create a CF with the Wet'suwet'en, so the involvement of the First Nation was not an afterthought, and the Wet'suwet'en weren't sold a predetermined project or methods of operation or management. It was collaboration and a lot of up-front discussion ... this has enhanced the relationship between the municipalities and the Wet'suwet'en." Board members indicated that learning about the interests of the Wet'suwet'en and how they wanted to be involved in the management of the CF and accommodating these learnings in practice has helped in working together. Evidence of this comes from the continued participation of the Wet'suwet'en and ways in which they describe their relationship with the CF. Data show that the CF has also financially supported forest user groups, worked to protect First Nation cultural values, and collaboratively designed informational posters, among other joint activities (Table 1).

\section{Discussion}

Our data revealed 14 collective actions that were taken by board members of the WCFC in managing the CF that corresponded with three main social learning outcomes described in the literature and found in the data. The data show that these actions did not just occur on their own. They happened as a result of social learning in which board members learned among themselves through their operations, their discussions together, and external sources [11], and either arrived at decisions and/or strengthened their common interests in relation to issues they decided to pursue and actions they took [22]. As discussed above, some of the linkages between learning and action were directly established by board members in the interviews we carried out, while others were established through review of documents (e.g., logging plans, annual reports) and forest visits to verify what action has really been taken as a result of the learning we were told had occurred.

Sharing benefits from operations, for instance, is a key area from the perspective of study participants where the board took action. This action occurred on three fronts and was based in part on the experiences they shared during discussions about what other CFs had done, the input of an experienced insider, and their own knowledge and perspectives [11]. Through these actions, the board took important steps in meeting its commitment to distribute profits from forestry operations to the community, an important shared interest of the board. Such actions also underpin an important theoretical and practical expectation of CF governance - sharing benefits with the community [30]. 
Data related to hiring local are also in keeping with the findings of the BC Community Forest Association as well as Furness and associates, who found that local employment was a significant community contribution in the CFs they studied [25,31]. In our study, it was difficult to determine the precise number of jobs provided to community members; however, the actions by the board to hire locally were reassuring for forestry professionals and community members whose livelihoods depend on the forest.

Some authors have described social learning as being capable of improving human-environmental relationships [16,32]. Improving such relationships requires a better understanding of issues or challenges, which in turn influences decision-making and actions. We found that the board's actions related to implementing an integrated forest management initiative, establishing legacy and silviculture funds, and adding value to logs resulted from a deepened or improved understanding of sustainable forest management and climate change issues and about running a CF as a business. This knowledge was in part built through learning together, board presentations, and sharing knowledge and experience around the table. Thus, through learning from forestry operations over the years and among themselves, board members were convinced that climate variability is very likely to continue to impact management of the landbase and, therefore, it was forward thinking, and in their interest to take action. As a result of experimenting with tree species not traditional to the area, the WCFC was able to gain insight into species that might tolerate climate variability and how to manage them, which may help in planning for future silviculture treatments in the face of climate change.

Furthermore, we found the board's trials on adding value to logs a concrete way of trying to diversify WCFC's operations. The inability to successfully run these business ventures highlight issues related to the small size of the landbase, economies of scale, and issues outside of the board's control such as the impact of tariffs on their operations. Although unsuccessful, working to add value to logs resulted in the board learning a lot about the forest products industry. The board took action, however, in the face of not finding viable ways to diversify by reducing their annual allowable cut and establishing legacy and silviculture funds in the hope of insulating their operations from economic downturns and other impacts on revenues.

The literature also established that building relationships among interested parties when managing natural resources is an important outcome of social learning [33] and can be essential to collective action, especially if that action involves shared interests [34]. The data related to the board's action toward building relationships were in line with both the social learning and collective action literature $[18,34]$. Egunyu and Reed, for example, found similar action on building relationships in their study of the Harrop-Procter Community Forest, which resulted in the CF developing good relationships with the BC Ministry of Forests, Lands, Natural Resource Operations and Rural Development [7]. The data showed that collective action outcomes such as incorporating the interests of forest groups into management are a result of the board continually learning the best ways to build relationships with these groups. In a province where forestry in recreation areas is contentious, finding ways to work with forest user groups is key. The board's approach was to stem any future conflict among forest user groups by working with them to help fulfil their goals. There is also greater opportunity and potential to enhance learning and action by working with these groups, as the data show.

Similarly, the decision to work closely with the Wet'suwet'en First Nation and pay attention to their interests, had positive results. Wet'suwet'en participants told us how much they appreciated that the WCFC was run much differently and producing positive experiences, in contrast to their negative experiences with large forest products companies. The difference is primarily a result of the board listening, learning, taking action when asked, and being accountable. For instance, the board experimented with propagating berries, an important component of the Wet'suwet'en culture, even though exclusive rights are not given to CFs to harvest non-timber forest products under the Community Forest Agreement [35], nor are rights granted to communities to access such forest resources [36]. 
Our findings also confirm the work of other authors [11,12] that extended engagement and deliberation are important to social learning in a natural resource management context. Such engagement can also lead to collective action, as we found in our case regarding WCFC's integrated resource management initiative and legacy fund establishment, which saw extensive back and forth engagement and deliberation among board members and other stakeholders before action was taken. Similar levels of engagement and deliberation were needed to understand the most appropriate ways to share benefits with the community and to run the WCFC as a business.

The data also show that the board recognized when outside help was needed to enhance learning among themselves, as evidenced by the learning done through employing the services of a financial planner and the work of researchers. It is clear that at least some of the information acquired from outside experts led to learning among board members and subsequent action.

However, we did not find much evidence of action and learning related to other possible collective action outcomes such as setting rules of conduct of the group, designing management rules, and monitoring decisions [24]. At the same time, we have data (not presented here) of at least the establishment of a policy committee that worked on governance rules for the organization that could be deemed a collective action outcome. The lack of action outcomes in this regard could be because when we looked for and talked about collective action and learning with participants, discussions with participants focused more on things obvious in the community as a whole and pertaining to the landbase, rather than more internal outcomes such as a policy framework. In other words, most of what participants spoke about were identifiable collective actions that impacted community members and/or affected the landbase.

\section{Conclusions}

The data presented in this paper provide further case evidence supporting the contention that social learning can result in collective action outcomes or that collective action is an outcome of social learning $[11,18]$. Our data from WCFC reveal strong evidence of collective action outcomes among board members such as establishing a legacy fund, adding value to logs, and protecting First Nations cultural values as well as the linkage of these to social learning. These action outcomes resulted from the interests board members shared, the learning they engaged in, and the collective decisions they made to achieve their goals. Our study also provides insights into the sorts of social learning activities and outcomes that generated such collective action, in that three (acquisition of (new) knowledge, improved understanding, and relationship building) social learning outcomes established through the research could be directly associated with the 14 collective action outcomes identified.

In considering the basic underpinnings of the collective action conceptual frame in our analysis, we found that having shared interests and engaging in collective decision making were key to action outcomes. Collective decision making was particularly important to both action and learning as it showed that the voluntary board members were united in their desire and common interest in making the $\mathrm{CF}$ successful in many ways but had to engage in learning and deliberative discussions to get there. A more holistic interpretation of the collective action conceptual frame to basically include anything the board did might have resulted in the identification of more collective action outcomes, but without evidence of associated social learning-the focus of this paper.

Our data also revealed that not all social learning activities or outcomes resulted in collective action even though strong evidence of learning was established. It surprised us, for example, that learning outcomes and the activities that facilitated them, such as trust building, did not result directly in action outcomes. This could be the result of the fact that the trust building we found in the learning data occurred mostly among board members, who were often interacting and discussing management of the forest as opposed to engaging regularly with other forest stakeholders. Regardless, we could not associate the trust-related learning outcomes to action outcomes, only to relationship-building outcomes, which could of course be an on-ramp to action on trust building. Also, the social learning outcomes that did result in collective action could have been initiated by completely new learning for 
board members that actually spurred them into action. This could include acquiring new knowledge about issues that demanded immediate attention (e.g., dealing with the mountain pine beetle outbreak), or deciding on activities they knew they wanted to engage in to differentiate themselves from industrial forestry (e.g., benefit sharing). Teasing these relationships out will require further study, but it is clear that identifying issues while managing a resource and having a common interest in finding a desirable outcome stimulates both learning and action.

Of course, all social learning does not have to result in action, since learning provides the foundation for further knowledge generation and understanding. In other words, action is not the only measure of effective social learning. In fact, "social learning research is change-oriented and most often interested in how social learning unfolds or is mediated and how it can influence action and adaptation" [37] (p. 45). The many criticisms of social learning in the learning literature for lacking a clear focus, providing empirical evidence to support or refute the theory's many assertions, and assumptions related to learning leading to collective action, can only help strengthen the theory. The empirical findings presented here will no doubt fuel further debate.

Author Contributions: The following are the contributions of the authors to this paper: conceptualization, A.A.; methodology, A.A. and A.J.S.; software, A.A.; validation, A.A.; formal analysis, A.A. and A.J.S.; investigation, A.A.; resources, A.J.S.; data curation, A.A. and A.J.S.; writing-original draft preparation, A.A. writing-review and editing, A.A. and A.J.S.; visualization, A.A. and A.J.S.; supervision, A.J.S.; project administration, A.A. and A.J.S.; funding acquisition, A.J.S.

Funding: This research was supported by the Social Sciences and Humanities Research Council of Canada (SSHRC).

Acknowledgments: The authors sincerely thank all participants for participating in this research and for sharing their knowledge and experience. Special thanks to board members and the then general manager, Bill Golding, for allowing their community forest to be our case study. The authors are also grateful to Gary Schneider for copy editing the manuscript.

Conflicts of Interest: The authors declare no conflict of interest in conducting this research and that the funders had no role in the design of the study; in the collection, analyses, or interpretation of data; in the writing of the manuscript, or in the decision to publish the results.

\section{References}

1. Rodela, R. Social learning, natural resource management, and participatory activities: A reflection on construct development and testing. NJAS Wagening. J. Life Sci. 2014, 69, 15-22.

2. Wal, M.; Kraker, J.D.; Offermans, A.; Kroeze, C.; Kirschner, P.A.; Ittersum, M. Measuring social learning in participatory approaches to natural resource management. Environ. Policy Gov. 2014, 24, 1-15.

3. Woodhill, J.; Röling, N.G. The second wing of the eagle: human dimension in learning our way to sustainable futures. In Facilitating Sustainable Agriculture: Participatory Learning and Adaptive Management in Times of Environmental Uncertainty; Röling, N.G., Wagemakers, M.A.E., Eds.; Cambridge University Press: Cambridge, UK; New York, NY, USA, 2000; pp. 46-69.

4. Buck, L.; Wollenberg, E.; Edmunds, D. Social learning in the collaborative management of community forests: Lessons from the field. In Social Learning in Community Forest Management; Wollenberg, E., Buck, D., Fox, J., Brodt, S., Eds.; Center for International Forestry Research and the East-West Center: Bogor Barat, Indonesia, 2001; pp. 1-20.

5. Pahl-Wostl, C.; Hare, M. Processes of social learning in integrated resources management. J. Community Appl. Soc. Psychol. 2004, 14, 193-206.

6. Fernandez-Gimenez, M.E.; Ballard, H.L.; Sturtevant, V.E. Adaptive management and social learning in collaborative and community-based monitoring: A study of five community-based forestry organizations in the western USA. Ecol. Soc. 2008, 13. Available online: http://www.ecologyandsociety.org/vol13/iss2/art4/ (accessed on 15 June 2018). [CrossRef]

7. Egunyu, F.; Reed, M.G. Social learning by whom? assessing gendered opportunities for participation and social learning in collaborative forest governance. Ecol. Soc. 2015, 20. Available online: https: //www.ecologyandsociety.org/vol20/iss4/art44/ (accessed on 25 June 2018). [CrossRef] 
8. Mostert, E.; Pahl-Wostl, C.; Rees, Y.; Searle, B.; Tabara, D.; Tippett, J. Social learning in European river-basin management: barriers and fostering mechanisms from ten river basins. Ecol. Soc. 2007, 12. Available online: https://www.ecologyandsociety.org/vol12/iss1/art19/ (accessed on 12 September 2018). [CrossRef]

9. Rist, S.; Chidambaranathan, M.; Escobar, C.; Wiesmann, U.; Zimmermann, A. Moving from sustainable management to sustainable governance of natural resources: The role of social learning processes in rural India, Bolivia and Mali. J. Rural Stud. 2007, 23, 23-37. [CrossRef]

10. Assuah, A. Learning for Sustainability through Community Forest Management. Master's Thesis, University of Manitoba, Winnipeg, MB, Canada, 2015.

11. Schusler, T.M.; Decker, D.J.; Pfeffer, M.J. Social learning for collaborative natural resource management. Soc. Nat. Res. 2003, 16, 309-326. [CrossRef]

12. Newig, J.; Günther, D.; Pahl-Wostl, C. Synapses in the network: Learning in governance networks in the context of environmental management. Ecol. Soc. 2010, 15, 24. Available online: https://www.ecologyandso ciety.org/vol15/iss4/art24 (accessed on 10 September 2018). [CrossRef]

13. Koontz, T.M. Social learning in collaborative watershed planning: The importance of process control and efficacy. J. Environ. Plan. Manag. 2014, 57, 1572-1593. [CrossRef]

14. Egunyu, F.; Reed, M.G.; Sinclair, J.A. Learning through new approaches to forest governance: Evidence from Harrop-Proctor community forest, Canada. Environ. Manag. 2016, 57, 784-797. [CrossRef] [PubMed]

15. Assuah, A.; Sinclair, A.J.; Reed, M.G. Action on sustainable forest management through community forestry: The case of the Wetzin'kwa Community Forest Corporation. For. Chron. 2016, 92, 232-244. [CrossRef]

16. Keen, M.; Brown, V.; Dyball, R. Social learning: A new approach to environmental management. In Social Learning in Environmental Management: Towards a Sustainable Future; Keen, M., Brown, V., Dyball, R., Eds.; Routledge: London, UK, 2005; pp. 3-21.

17. Ducrot, R. Gaming across scale in peri-urban water management: contribution from two experiences in Bolivia and Brazil. Int. J. Sustain. Dev. World Ecol. 2009, 16, 240-252. [CrossRef]

18. Cundill, G.; Rodela, R. A review of assertions about the processes and outcomes of social learning in natural resource management. J. Environ. Manag. 2012, 113, 7-14. [CrossRef] [PubMed]

19. Biedenweg, K.; Monroe, M. Teasing apart the details: How social learning can affect collective action in the Bolivian Amazon. Hum. Ecol. 2013, 41, 239-253. [CrossRef]

20. Ostrom, E. Understanding Collective Action. In Collective Action and Property Rights for Sustainable Development; Meinzen-Dick, R.S., Gregorio, M.D., Eds.; International Food Policy Research Institute: Washington, DC, USA, 2004.

21. Collective Action and Property Rights. Resources, Rights and Cooperation: A Sourcebook on Property Rights and Collective Action for Sustainable Development; International Food Policy Research Institute: Washington, DC, USA, 2010.

22. Meinzen-Dick, R.S.; Greogorio, M.D.; McCarthy, N. Methods for studying collective action in rural development. Agric. Syst. 2004, 82, 197-354. [CrossRef]

23. Allen, K.; Frank, D. Community forests in British Columbia: Models that work. For. Chron. 1994, 70, 721-724. [CrossRef]

24. Gunter, J.; Mulkey, S. Essential background: A short history of community forestry in British Columbia. In The Community Forestry Guidebook II: Effective Governance and Forest Management; Mulkey, S., Day, K., Eds.; FORREX Forum for Research and Extension in Natural Resources, Kamloops and British Columbia Community Forest Association: Victoria, BC, Canada, 2012; pp. 1-4.

25. British Columbia Community Forest Association. Status of Community Forestry in British Columbia; British Columbia Community Forest Association: Victoria, BC, Canada, 2018.

26. Yin, R.K. Case Study Research: Design and Methods; Sage Publications: Thousand Oaks, CA, USA, 2003.

27. Duinker, P.; Matakala, N.P.; Chege, F.; Bouthillier, L. Community forests in Canada: An overview. For. Chron. 1994, 70, 711-719. [CrossRef]

28. Teitelbaum, S.; Beckley, T.; Nadeau, S. A national portrait of community forestry on public land in Canada. For. Chron. 2006, 82, 416-428. [CrossRef]

29. Wetzinkwa Community Forest Strategic Planning Retreat. Defining the Future We Want to Create; Wetzinkwa Community Forest Corporation: Smithers, BC, Canada, 2011.

30. Teitelbaum, S. Criteria and indicators for the assessment of community forestry outcomes: a comparative analysis from Canada. J. Environ. Manag. 2014, 132, 257-267. [CrossRef] [PubMed] 
31. Furness, E.; Harshaw, H.; Nelson, H. Community forestry in British Columbia: policy progression and public participation. For. Policy Econ. 2015, 58, 85-91. Available online: http://orca.cf.ac.uk/86230/1/Furness\% 20et\%20al.\%202015\%20-\%20Accepted\%20author\%20manuscript\%20-\%20Community\%20Forestry\%20in \%20British\%20Columbia\%20Policy\%20Progression\%20and\%20Public\%20Participation.pdf (accessed on 20 September 2018). [CrossRef]

32. Armitage, D.; Marschke, M.; Plummer, R. Adaptive co-management and the paradox of learning. Glob. Environ. Change 2008, 18, 86-98. [CrossRef]

33. Cundill, G. Monitoring social learning processes in adaptive co-management: three case studies from South Africa. Ecol. Soc. 2010, 15, 28. Available online: https://www.ecologyandsociety.org/vol15/iss3/art28/ (accessed on 20 July 2018). [CrossRef]

34. Doss, C.R.; Meinzen-Dick, R. Collective action within the household: insights from natural resource management. Wold Dev. 2015, 74, 171-183. [CrossRef]

35. Davis, E.J. Non-timber forest product development in British Columbia's community forests and small woodlands: Constraints and potential solutions. In Land Management Handbook 67; British Columbia Ministry of Forest and Range, Forest Science Program; and Centre for Livelihoods and Ecology, Royal Roads University: Victoria, BC, Canada, 2011.

36. McIlveen, K.; Bradshaw, B. A preliminary review of British Columbia's Community Forest Pilot Project. West. Geogr. 2005, 15, 68-84.

37. Cundill, G.; Lotz-Sisitka, H.; Mukute, M.; Belay, M.; Shackleton, S.; Kulundu, I. A reflection on the use of case studies as a methodology for social learning research in sub Saharan Africa. NJAS Wagening. J. Life Sci. 2014, 69, 39-47. [CrossRef]

(C) 2019 by the authors. Licensee MDPI, Basel, Switzerland. This article is an open access article distributed under the terms and conditions of the Creative Commons Attribution (CC BY) license (http://creativecommons.org/licenses/by/4.0/). 